\title{
Every On chairing a campus Librarian \\ committee
}

a Leader

\author{
By Priscilla Atkins and Jean L. Loup
}

\section{Two librarians describe their experiences as leaders}

n May 2, 1996, the Academic and Research Libraries Division of the Michigan Library Association presented Becoming Beyond-Library-Walls Leaders, a one-day program of speeches and conversations on a topic that is-and will continue to be-on the minds of many academic librarians. The keynote address was given by then ACRL president Patricia Senn Breivik. As part of the reactor panel following Breivik's speech, two librarians, Priscilla Atkins and Jean Loup, spoke about their particular experiences involving beyond-library-walls leadership. Following are their speeches.

\section{Leadership at Hope College}

\section{By Priscilla Atkins}

When I first sat down to think about what aspects of my experiences as chair of the Committee on Women's Studies \& Programs at Hope College would be meaningful to share, I tried to focus on the general, and hence broadly applicable facets of my own experience. For instance: serving on a committee gives the library visibility, allows for networking within the larger community, lets librarians meet face-to-face with faculty in a setting other than the library, offers an opportunity to slip in advertising for the library's services, etc. But I realized one could deduce these phenomena from common sense, that I had been aware of them before I ever served on a campus committee, that there was no sense telling you what you already knew. So I decided to share some of the nitty gritty details from my own particular experience.

\section{Getting involved}

At Hope College, faculty (and librarians are considered faculty there) are asked at the end of each year what committees they have an interest in serving on. In the spring of 1995 , the end of my first year as a reference librarian at the Hope College Library, I indicated an in- terest in the Committee on Women's Studies \& Programs. In fact, due to confusion on my part, I actually told the Provost's Office that I thought I already was on this committee. Earlier in the year I had answered a campus e-mail query from the woman (whom I'd never met) who organizes Women's Week at Hope. She then invited me to be on a committee to help plan the following year's Women's Week. When the "Call for Committee Volunteers" arrived from the Provost's Office in the spring of my first year at the college, I didn't know what to make of it: either I hadn't been told or I wasn't listening to know this happened every year, that I should give the names of several committees, that librarians usually aren't appointed to committees early on in their careers. In my ignorance, I was fearful of being appointed to too many committees-not too few. So when I responded, I said something to the effect that I thought serving on the Women's Committee would be enough, not realizing that these are officially decided appointments, and certainly not positions one appoints oneself to. The provost was gracious enough to overlook my lack of experience, and during the summer I was informed of my appointment to the Committee on Women's Studies and Programs.

(Alkins cont. on page 654) 


\section{Leadership at the University of Michigan}

\section{By Jean L. Loup}

What was my role beyond library walls? In early 1994 I was elected chair of the faculty of the University of Michigan (UM) for a one-year term beginning May 1, 1994. This role involved chairing the faculty's Executive Committee during its weekly meetings, the agendas of which included an hour once a month with both the president and the provost. I also chaired the monthly meetings of the Faculty Senate Assembly and the annual meeting of the faculty.

How did I get there? I had been active in faculty governance and the local chapter of the American Association of University Professors (AAUP) for 20 years, including service on a number of faculty committees and a term as president of the AAUP chapter. I had also served an earlier term on the faculty's Executive Committee and had chaired the University's Budget Priorities Committee, a faculty/administration committee advisory to the provost on academic budget matters.

What was happening there? The climate for faculty governance in 1993-94 at UM had become seriously strained. Communication between this elected faculty group and the president and provost was clifficult at best, and in response those faculty elected to the group were angry and ready to take some action against the university and its leadership. At the first meeting in May, my first as chair, they voted to challenge the provost to take action on a grievance matter and threatened him with a vote of censure.

What is interesting at this point-especially now that I look back-is how much support I had-informal, behind-the-scenes supportwhich helped to defuse the situation. By fall 1994 the president was making a good effort at listening to the concerns of the faculty, and the whole situation began to lose its crisis nature.

What experience did I have? Because we librarians do so much of our work through committees, I took to this campuswide position the knowledge of how to do my committee home- work, the importance of attendance and being on time, how to contribute to the discussion, and how to run a meeting. These skills are not common among all faculty, and in a wider campus setting they give librarians a credilility from which we benefit.

What knowledge of the campus did I have? We often speak of the library being the heart of the university without recognizing how this provides us with a breadth of knowledge about the institution that few faculty have. We read the campus newspapers, the Chronicle of Higher Education, and other materials that keep us aware of what is happening on campus and in higher education more broadly. I took this awareness with me-awareness of campus and national issues-and it proved beneficial.

What on-the-job skills did I have? We librarians have a number of on-the-job skills, required by our work, which prove to be invaluable in a campuswide setting. We know how to find information, we know how to negotiate (e.g., the reference interview or cataloging decisions), we know how to plan and how to implement a plan, we are good problem solvers, and we have an ability to listen. I took these skills to a situation

in which I found myself flying by the seat of my pants, especially in those first few months. If these skills had not been well established, I could not have been effective.

There's one other skill that we learn, especially at the reference desk: how to keep what we are thinking from showing on our facewhat an important skill to have when one is dealing with angry faculty or aclministrators! And a corollary: I was told later that I had the facility of putting an issue on the table without emotion which enabled discussion to occur.

What did this leadership experience mean to the library? During my year as chair, librarians at the University of Michigan gained emeritus status. This had been in the wings, but finally moved forward. In addition, the library received funding for three positions from a pool reserved for faculty appointments. There

(Loup cont. on page 655) 


\section{(Atkins cont. from paye 652)}

\section{An introvert steps forward}

In August, much to my surprise, I received a message from the Provost's Office asking if I would be willing to chair the committee. Since my prior experience in academic librarianship was at an institution where the librarians were not on equal footing with the faculty, at least not as far as campus governance goes, this was heady and slightly frightening news. The "fright" was for at least a couple of reasons. First, I am an introvert to the point that I have been called "skewed" on the Myers-Briggs Type Indicator. I like being with people one-on-one and, oddly enough, I love teaching, but chairing a com- that is affiliated with the Reformed Church of America. The affiliation with a particular denomination does not mean that Hope College expects or wants all faculty and students to hold the same beliefs and views; it does mean that it takes the whole person-mind, body, and spirit-seriously. In January the dean of the Chapel at Hope College gave a sermon regarding the use of masculine language to speak about God. To promote discussion and ensure that more than one viewpoint was presented on this theological topic, the committee helped sponsor a presentation and discussion entitled "God, Mom \& Apple Pie: Is It All Right to Call God Mother?" There was a large student turnout to this evening event at which lively discussion took place. I was fortunate to have been able to help by organizing the planning sessions prior to the event, not to mention helping to see that all of the pie got eaten.

Another issue that the committee addressed concerned the proposal of a new core curriculum, which had been in development for more than a year. The committee was pleased that the proposal designated courses across the curriculum to include cultural diversity components. However, flagging courses on paper does not a reality make. To help ensure a successful integration of these components, the committee wrote a letter to the Academic Affairs Board outlining specific steps that needed to be taken. For instance, departments would need to have a method for assessing the courses flagged for cultural diversity. As chair, I wrote and sent the letter. To do so required a closer reading of the proposal than I had done previously. It also meant giving more thought to issues I really do care about than I would have otherwise.

A final example of this year's activities is the committee's attention to the failure of the college to appoint a sexual harassment policy educator, a position integral to the effective implementation of the Sexual Harassment Policy. This involved a memo to yet another board and a follow-up meeting with the president of the college. I wrote the former, and led the delegation to the latter. Since the Faculty Handbook names the president as the person who appoints the educator, I approached my responsibilities with some trepidation (librarians at Hope have faculty status, but are nontenure track); however, it was again worthwhile and even interesting to take the time to 
study the "Policy Statement on Sexual Harassment and Grievance Procedure" in the Faculty Handbook.

\section{Opportunities open up}

This brief overview of some of the committee's work hopefully gives a sense of the type of activities this librarian was involved with outside the library walls. I can honestly say that this work was both fulfilling and enjoyable. Yes, I was in the hot seat on at least one occasion, and yes, I sometimes felt I was putting myself at risk, but if I am asked to serve as chair again, I will. Not only did it allow me to use some of my talents to serve a good cause, it also opened up opportunities I didn't even know existed. For instance, I was invited to attend a regional women's studies conference, and the director of women's studies has suggested to the administration that I take a more active role in women's studies leadership by attending a series of triannual regional meetings in the upcoming academic year.

\section{Inviting oneself to the table}

Finally, I want to echo a couple of thoughts that Patricia Senn Breivik spoke of in her keynote address: the wisdom in inviting oneself to the table and the importance of participation in community. Although I arrived on the Committee on Women's Studies \& Programs by accident and was named chair by default (nobody else was willing or able), in the future I will be more assertive about my willingness to serve. In the age of the global community it is clear that we all live in many communities. The academic communities in which we librarians live can and should be influenced and cared for by us. We can make a difference.

\section{(Loup cont. from page 653)}

had been hesitation about including librarian appointments until the chair of the faculty was a librarian. Other than these concrete examples, I think it is too soon to assess the long-term impact on the library.

\section{One other lesson for librarians}

One final lesson, which I think is absolutely critical: we as librarians need to act with confidence in our skills and abilities, assuming we have the respect of the faculty, rather than be apologetic for not having a doctorate or other credentials.



